\title{
Umacnianie więzi małżeńskich i rodzinnych na podstawie działalności fundacji Rodzina w Służbie Człowieka w Rychwałdzie
}

Podmiotem troski Kościoła jest człowiek w całej rozciągłości i złożoności swojej egzystencji. W wielu wymiarach i aspektach - jako jednostka i jako członek większej społeczności. Zbawienie człowieka zawsze odbywa się tu i teraz, w konkretnej historii, w czasie, w konkretnej sytuacji geopolitycznej. Wiele różnych dziedzin nauki zajmuje się człowiekiem i żadna z nich nie wyczerpała tematu. Choć niewątpliwie trzeba stwierdzić, że współczesne technologie pozwalają na bliższe przyglądnięcie się naturze i tajemniczości zjawiska, jakim jest istota ludzka, to jednak każda odpowiedź otwiera zupełnie nowe perspektywy i przyczynia się do zadawania coraz to nowszych pytań, które oczekują na odpowiedzi. Jest jednak i druga strona współczesności, która wypływa z tego samego źródła, ale doprowadza do zupełnie innej konkluzji i wynikającej z niej postawy. Świadomość znacznej złożoności rzeczywistości, doświadczanie jej skomplikowania w połączeniu ze specjalizacją w poszczególnych dziedzinach wiedzy i niemożność sformułowania jasnych, jednoznacznych odpowiedzi sprawia, że współczesny człowiek 
zaprzestaje poszukiwań i zadawania trudnych pytań. Jest to zjawisko niebezpieczne, ponieważ brak refleksji i autoświadomości, brak poszukiwania odpowiedzi zubaża człowieka, całe społeczeństwo i niebezpiecznie spłyca wartość egzystencji człowieka.

Człowiek zawsze był i jest postrzegany w dwóch wymiarach: jednostkowym i w odniesieniu do drugiego człowieka, czyli w wymiarze społecznym. Rodzi się dzięki innym, wzrasta dzięki innym i dzięki innym staje się człowiekiem. Bycie członkiem społeczności ludzkiej nie przekreśla jednak w żadnej mierze człowieka jako jednostki. Co więcej, im bardziej jest on jednostką ze wszech miar dojrzałą, stabilną, świadomą, tym większym dobrem może ubogacać innych, wspólnotę, społeczeństwo. Można powiedzieć, że te dwa wymiary człowieka spotykają się w małżeństwie i w rodzinie. Mimo że obie te rzeczywistości są zjawiskiem bardzo powszechnym, nie można powiedzieć, że zostały w pełni poznane i opisane.

W niniejszym artykule podejmuję krótką refleksję nad zjawiskiem rodziny w kontekście działań podjętych na jej rzecz, realizowanych przez ludzi dobrej woli, dostrzegających wartość życia rodzinnego i małżeńskiego oraz reagujących w konstruktywny sposób na zaistniałe problemy.

\section{Kościół na straży rodziny}

„Pośród [...] wielu dróg rodzina jest drogą pierwszą i z wielu względów najważniejszą. Jest drogą powszechną, pozostając za każdym razem drogą szczególną, jedyną i niepowtarzalną, tak jak niepowtarzalny jest każdy człowiek. Rodzina jest tą drogą, od której nie może się on odłączyć. Wszak normalnie każdy z nas w rodzinie przychodzi na świat, można więc powiedzieć, że rodzinie zawdzięcza sam fakt bycia człowiekiem”1.

Kościół niezmiennie przypomina prawdę o wartości rodziny. Wartość jej uzasadnia samą naturą człowieka, pokazując, że jest to rzeczywistość jak najbardziej podstawowa. Rodzina ma wiele uniwersalnych i ponadczasowych cech oraz wartości. Już Arystoteles pisał o niej jako istniejącej z natury wspólnocie. Badania etnologiczne pokazują, że jest ona charakte-

1 Jan Paweł II, List do rodzin, w: Jan Paweł II, Rodzino, co mówisz o sobie? Dokumenty i przemówienia papieskie w Roku Rodziny, Kraków 1995, s. 59. 
rystyczna dla całej ludzkości, wszystkich czasów i kultur². Nauka o wartości rodziny jako podstawowej i pierwotnej, wyprzedzającej wszelkie inne strukturze społecznej, ma wymiar ogólnoludzki i uniwersalny. „Z rodziną łączą się podstawowe wartości, których nie wolno naruszać bez nieobliczalnych wręcz szkód, natury moralnej"3, zarówno dla pojedynczego człowieka, jak i całego społeczeństwa. Kościół wzywa niezmiennie do czujnego i odpowiedzialnego zaangażowania na rzecz rodziny, nie tylko chrześcijan, ale całe społeczeństwo ${ }^{4}$. Chrześcijaństwo prawdę o wartości rodziny wynikającej z prawa naturalnego ${ }^{5}$ ubogaca, ukazując jej nadprzyrodzony charakter ${ }^{6}$.

Już w okresie poapostolskim rodzina była postrzegana jako Kościół domowy, mały Kościół, Kościół w domu. Te dwie rzeczywistości: Kościół i rodzina wywodzą się z tego samego źródła, z Tajemnicy Boga ${ }^{7}$. Ta naturalna wspólnota mężczyzny i kobiety jest odbiciem Bożej dobroci oraz żywym i wymownym wizerunkiem miłości Trójcy Świętej. Łaska Boża, która jest jak ożywczy świeży strumień miłości, wchodzi w życie małżonków poprzez sakramenty ${ }^{8}$, uświęca je, umacnia i uzdrawia. Sobór Watykański II w konstytucji Gaudium et spes poświęca rodzinie osobny rozdział, w którym wprost mówi o jej promocji i przypomina współczesnemu światu o jej godności. Papież Paweł VI w encyklice Humane vitae (1968) ostrzega przed niebezpieczeństwem hedonistycznego egoizmu zagrażającego żywotności rodzin. Adhortacja apostolska Familiaris consortio (1981) ukazuje duszpasterstwo rodzin jako fundament i pierwszoplanowy cel nowej ewangelizacji. Papież

2 A. Świerczek, Wolne związki w świetle nauczania Kościoła o małżństwie, Kraków 2013, s. 16-17.

3 T. Borutka, A. Świerczek, Rodzina silna Bogiem. Teologiczno-duszpasterska refleksja na temat rodziny, Kraków 2013, s. 15.

4 Jan Paweł II, „Czym jesteś, rodzino chrześcijańska?” - przemówienie Ojca Świętego 8 października 1994 r., w: Rodzino, co mówisz..., dz. cyt., s. 234.

5 Jan Paweł II, Modlitwa niedzielna z papieżem. Fundament rodziny - Prawo naturalne, w: Jan Paweł II, Rodzino, co mówisz..., dz. cyt., s. 406.

6 H. Lombaerts, E. Osewska, Family and Family Catechesis. A Matter of Diversification, „Acta Paedagogica Vilenensia” (2008) vol. 20, s. 225-243; E. Osewska, Jakość życia wspólnotowego rodziny jako podstawa skuteczności wychowania, „Roczniki Nauk o Rodzinie” (2013) t. 5, s. 5-22; E. Osewska, Wspólnota rodzinna $w$ stużbie wychowania, „Family Forum” 4 (2014), s. 125-139; J. Stala, Christliche Wahrheiten als Fundament einer inhaltsreichen Religionserziehung in der Familie, „The Person and the Challenges” 5 (2015) nr 2, s. 137-148; J. Stala, Geistig behinderte Kinder religiös erziehen - Herausforderungen an Pädagogik und Katechese, „The Person and the Challenges” 4 (2014) nr 2, s. 221-234.

$7 \quad$ Jan Paweł II, „Czym jesteś, rodzino chrześcijańska?”..., dz. cyt., s. 231.

8 Jan Paweł II, „Czym jesteś, rodzino chrześcijańska?”..., dz. cyt., s. 234. 
Jan Paweł II mówił i pisał o rodzinie, małżeństwie bardzo wiele. Czynił to

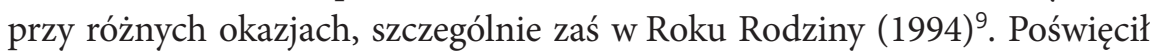
temu tematowi również cały cykl katechez środowych Mężczyzną $i$ kobieta stworzył ich. Za jego pontyfikatu powołane zostały również w Kościele nowe struktury, mające służyć dobru rodziny: Papieska Rada ds. Rodziny oraz akademicki Instytut Studiów nad Małżeństwem i Rodziną ${ }^{10}$. Jan Paweł II został nazwany papieżem rodziny, doceniał jej znaczenie, a o obecnym czasie mówił jako o epoce rodziny. Dostrzegał w niej szansę uzdrowienia współczesnych bolączek poprzez dawanie świadectwa otwartości, poświęcenia i wielkoduszności. Nawoływał je do ochrony i otaczania opieką każdego człowieka. Taka postawa chrześcijańskich rodzin, będąca świadectwem miłości życia, uczyni z nich twórców kultury życia i cywilizacji miłości ${ }^{11}$.

\section{Rodzina współcześnie - zarys problemów}

Rodzina zawsze była uważana za podstawową jednostkę społeczną. Poprzez podejmowanie zadań prokreacyjnych i wychowawczych zapewniała stabilność demograficzną państwa. Dbając o byt materialny członków rodziny i zaspokajanie nie tylko podstawowych potrzeb, przyczyniała się do pomnożenia dóbr materialnych swoich i społeczeństwa. Między rozwojem pomyślności rodziny i społeczeństwa widoczna była ścisła korelacja ${ }^{12}$. Role i zadania rodziny w stosunku do jednostki i społeczeństwa są fundamentalne i nie do przecenienia ${ }^{13}$. Jednak obecnie ta podstawowa grupa społeczna, będąc w samym centrum życia współczesnego człowieka, tak jak on i jego otoczenie ulega przeobrażeniom. Wskutek przemian cywilizacyjnych następuje zmiana modelu życia rodzinnego, który musi odpowiadać ciągle zmieniającej się rzeczywistości. Rodzina musi nadążyć za tempem, jaki narzuca współczesność ${ }^{14}$. Zmienia się model życia rodzinnego, przekształcają się re-

9 Dokumenty i przemówienia papieskie z tego roku znajdziemy wopracowaniu A. Świerczka, Rodzino, co mówisz o sobie?..., dz. cyt.

10 Jan Paweł II, „Czym jesteś, rodzino chrześcijańska?”..., dz. cyt., s. 233-234.

11 Jan Paweł II, „Czym jesteś, rodzino chrześcijańska..., dz. cyt., s. 235.

12 A. Świerczek, Wolne związki..., dz. cyt., s. 7.

13 A. Świerczek, Wolne związki..., dz. cyt., s. 114.

14 R. Boguszewski, Współczesne znaczenie rozumienia rodziny w Polsce, „Zeszyty Naukowe KUL” 59 (2015) nr 4 (232), s. 127, https://www.kul.pl/files/102/articles/2015_4/ zn_kul_2015_4_a_boguszewski.pdf (12.09.2018). 
lacje pomiędzy jej członkami. Zmiany te są faktem. Nie przebiegają jednak bezproblemowo, współczesne rodziny dotykają bowiem poważne kryzysy. Ich przejawami są rozwody, separacje małżonków. Niepokojącym zjawiskiem jest odraczanie przez ludzi młodych decyzji o zawarciu małżeństwa. Rośnie popularność tzw. wolnych związków. Niektórzy rezygnują z potomstwa lub odkładają tę decyzję na dalszą, bliżej nieokreśloną przyszłość. Wzrasta też liczba rodziców samotnie wychowujących dzieci ${ }^{15}$. Oprócz tych zjawisk znakiem kryzysu ,jest podważenie istotnych prawd i definicji małżeństwa i rodziny" ${ }^{16}$. Dzieje się to nie tylko w sferze opinii publicznej, ale niestety także na poziomie międzynarodowych organizacji czy państw. Wystarczy wspomnieć o zrównywaniu w prawach z małżeństwami wolnych związków i związków homoseksualnych ${ }^{17}$. Zjawiska będące przejawem kryzysu rodziny nie mogą być rozpatrywane tylko jako element życia społecznego czy kulturowego. Bardzo często za liczbami statystyk kryją się ludzkie dramaty, rozczarowania bądź poważne problemy. Jednak wobec tego procesu degradacji kulturowej i społecznej, wyrażających się również w takich niepokojących zjawiskach jak przemoc, narkomania, zorganizowana przestępczość - to właśnie rodzina mocna, zjednoczona, zdrowa może się im skutecznie przeciwstawić. Uczynić to może poprzez kształtowanie społecznych cnót: solidarności, gościnności, lojalności, szacunku dla godności drugiego człowieka ${ }^{18}$. Równocześnie warto zaznaczyć, że szczęśliwa rodzina cały czas jest na pierwszym miejscu priorytetów ludzi XXI wieku. Jest wskazywana jako cel, do którego warto dążyć. Polacy cały czas doceniają jej wartość, mimo że statystyki wykazują nieco wartości spadkowe w porównaniu z latami poprzednimi ${ }^{19}$. Widoczne problemy rodziny skłaniają niektórych do ogłoszenia jej zmierzchu i potraktowaniu jej jako instytucji przestarzałej i nieprzystającej do współczesności ${ }^{20}$. Nie można się z taką diagnozą zgodzić, ponieważ stoi ona w sprzeczności z potrzebami człowieka, który ze swej natury jest istotą społeczną i staje się człowiekiem we

\footnotetext{
15 R. Boguszewski, Wspótczesne znaczenie..., dz. cyt., s. 127.

16 A. Świerczek, Wolne zwiazki..., dz. cyt., s. 7.

17 A. Świerczek, Wolne zwiazki..., dz. cyt., s. 7.

18 Jan Paweł II, „Czym jesteś, rodzino chrześcijańska?”..., dz. cyt., s. 234.

19 R. Boguszewski, Współczesne znaczenie..., dz. cyt.,., s. 128.

20 A. Minorczyk, K. Domagała, Śląska rodzina pęka: Małżeństwo to przeżytek-opinie, https://dziennikzachodni.pl/slaska-rodzina-peka-malzenstwo-to-przezytek-opinie/ar/581 763 (13.09.2018).
} 
wspólnocie z innymi. Potrzebuje drugiego człowieka. Te potrzeby realizowane są w rodzinie i poprzez nią.

Rodzina i jej kondycja zależą w dużej mierze od kondycji każdego z jej członków. Jesteśmy ludźmi i do naszej ludzkiej egzystencji przypisany jest grzech i jego konsekwencje. Dlatego „przyszłość świata i rzeczywiste szczęście człowieka zależy w dużej mierze od tego, czy w codziennym życiu konkretnych rodzin będzie realizował się zamysł Stwórcy"21. Innej drogi nie ma, jedynie wprowadzenie do życia rodzin Bożego ładu poprawi jej sytuację. Małżonkowie, przyjmując go, nie będą zubożeni w swej wzajemnej miłości, niczego nie utracą, ale przeciwnie - dopiero wtedy doświadczą pełni wzajemnego oddania 22 .

\section{Mocne więzi podstawą rodziny}

„Rodzina - to naprzód dobro «bycia razem»: bycie razem stanowi istotne dobro małżeństwa (stąd jego nierozerwalność) oraz wspólnoty rodzinnej"23. To bycie razem dokonuje się w relacjach pomiędzy członkami rodziny. Rodzina zaczyna się w relacji między kochającymi się ludźmi. To owa chęć bliskości, bycia razem, obdarowania sobą drugiej osoby, fascynacja i wiele innych mniej lub bardziej racjonalnych powodów składają się na miłość, czyli więź, która leży u podstaw małżeństwa i rodziny. Więź między małżonkami daje początek rodzinie i jest istotna nie tylko na początku wspólnej drogi, ale zawsze. Podstawą dobrej rodziny jest dobre małżeństwo. Więzi łączące małżonków określane są mianem komunii osób, gdzie miłość jest ich wspólnym dobrem ${ }^{24}$. Na tej miłości budowane jest całe życie rodzinne, relacje między samymi małżonkami, między nimi a dziećmi. W tych wzajemnych relacjach podstawą muszą być wartości. Świat wartości jest skałą człowieczeństwa, dlatego niebezpieczne jest zjawisko polegające na odchodzeniu od nich, wyzbywanie się zasad. Zaburza to bowiem poczucie tożsamości, która leży u podstaw budowania trwałych struktur społecz-

\footnotetext{
21 Źródła duchowości małżeńskiej, red. K. Lubowicki, Kraków 2012, s. 15.

22 Jan Paweł II, Nieprzemijające wartości Encykliki - do uczestników sympozjum zorganizowanego z okazji 25-lecia ogłoszenia encykliki „Humanae vitae” 26 listopada 1993, w: Rodzino, co mówisz...., dz. cyt., s. 172.

23 Jan Paweł II, Dziesięcioro przykazań, Kraków 2012, s. 29.

24 T. Borutka, A. Świerczek, Rodzina silna..., dz. cyt., s. 46.
} 
nych, w tym rodziny ${ }^{25}$. Podstawową, wymienioną już wartością, w oparciu o którą tworzą się autentyczne więzi w rodzinie, jest miłość. Dalej otwartość i docenianie wartości życia, swojego i innych. Niezbędna jest prawda ${ }^{26}$. Cała prawda o człowieku. To ona wedle słów Jezusa może nas naprawdę wyzwolić ${ }^{27}$, ponieważ godność człowieka jest z wolnością istotowo związana. Jest ona podstawowym prawem człowieka. Tylko w niej i poprzez nią człowiek może się realizować i odpowiedzialnie kierować swoim życiem² ${ }^{28}$. Aby rodzina była zdrowa i silna, muszą w niej panować również sprawiedliwość i pokój. Obie wartości są w istotny sposób związane z wartością miłości i wspólnie są sposobem na życie i działanie w rodzinie ${ }^{29}$.

Rola więzi emocjonalnych w rodzinie jest nie do przecenienia. Budują życie i funkcjonowanie tu i teraz, ale również określają przyszłość swoich członków - szczególnie dotyczy to dzieci, dla których życie rodzinne jest pierwszym środowiskiem społeczno-emocjonalnym. W rodzinie, na przykładzie relacji przeżywanych i obserwowanych, dziecko buduje modele swoich zachowań. Poczucie głębokich więzi emocjonalnych z rodziną jest warunkiem osiągnięcia dojrzałości emocjonalnej przez dziecko, rozumianej jako świadome kierowanie swoim zachowaniem i umiejętność przystosowania się do środowiska społecznego ${ }^{30}$. Nie jest przesadą stwierdzenie, że dom rodzinny uczy życia w społeczeństwie. Dla rozwoju i podtrzymania więzi rodzinnych bardzo ważne są: miłość małżeńska i rodzinna, atmosfera domu i zaspokojenie potrzeb psychicznych i społecznych. Realizuje się to, gdy należycie wypełniane są funkcje rodzicielskie, a rodzice reprezentują właściwe postawy. Do prawidłowego rozwoju dziecka potrzebny jest dom, w którym oboje rodziców żyje ze sobą w trwałej, uczuciowej więzi, czyli po prostu kochają się wzajemnie. To jest podstawą podejmowanego wspólnie

25 A. Świerczek, L. Kocik, Wieża Babel. Obraz rodziny w ponowoczesności, Kraków 2017, s. 46.

26 Z. Struzik, Zagrożenia podstawowych norm i zasad wychowania $w$ rodzinie na podstawie nauczania Jana Pawła II, w: Wsparcie rodziny. Założenia i praktyka w ujęciu interdyscyplinarnym, red. A. Regulska, A. Najda, Warszawa 2017, s. 35.

27 Por. J 8, 32.

28 Z. Struzik, Zagrożenia podstawowych norm i zasad wychowania $w$ rodzinie na podstawie nauczania Jana Pawła II, w: Wsparcie rodziny. Założenia i praktyka..., dz. cyt., s. 38.

29 Z. Struzik, Zagrożenia podstawowych norm..., dz. cyt., s. 40-41.

30 S. Cudak, Znaczenie więzi emocjonalnych $w$ rodzinie dla prawidłowego funkcjonowania dzieci, „Pedagogika Rodziny” (2012) 2/4, s. 32, http://bazhum.muzhp.pl/media//files/ Pedagogika_Rodziny/Pedagogika_Rodziny-r2012-t2-n4/Pedagogika_Rodziny-r2012-t2-n4-s31-39/Pedagogika_Rodziny-r2012-t2-n4-s31-39.pdf (23.08.2018). 
trudu wychowania dzieci, starania się, by razem zapewnić im odpowiednie warunki życia poprzez zaspokajanie potrzeb materialnych i umożliwiających rozwój duchowy. W prawidłowo funkcjonującym małżeństwie role rodzicielskie wzajemnie się uzupełnią i dopełniają. Harmonijne zaś relacje między małżonkami tworzą korzystny klimat uczuciowy, zaspokajający potrzeby psychiczne dziecka. Wszystkie te elementy w przyszłości mogą zaowocować jego dojrzałą, przystosowaną społecznie osobowością ${ }^{31}$.

Rodzinę tworzą ludzie, z całym bogactwem zachowań i postaw. Dlatego jest to rzeczywistość ciągle zmieniająca się, skomplikowana. Raz osiągnięty stan harmonii nigdy nie jest już „na zawsze”. Każdy ciągle i nieustannie musi o relacje, więzi rodzinne troszczyć się i zabiegać. Szczęśliwa rodzina jest pragnieniem wielu ludzi, stawiana na pierwszym miejscu życiowych celów. I jest źródłem prawdziwego szczęścia.

\section{Działalność Fundacji Rodzina w Służbie Człowieka - konstruktywna odpowiedź}

Rodzina to dobro „bycia razem”, pisał nasz święty papież Jan Paweł II. Dalej dodaje, że „dobro to można również określić jako dobro podmiotowości. Osoba jest podmiotem i rodzina jest podmiotem, ponieważ tworzą ją osoby"32.

Działania na rzecz rodziny, jej wsparcia, pomaganie jej w przezwyciężeniu trudności czy eliminowaniu dysfunkcji jest niewątpliwie zadaniem trudnym, bo wieloaspektowym i na polu różnych wymiarów. Ważne są wszelkie działania strukturalne państwa realizowane w ramach tzw. polityki społecznej. Mamy wiele różnych instytucji, które zostały powołane w celu wspierania rodzin, szczególne tych, których dysfunkcyjne funkcjonowanie wymaga zdecydowanych interwencji. Jednak rodzina może być wspierana wcześniej, zanim problemy będą wymagały działań instytucjonalnych.

Rodziną, jej stanem i dobrem kieruje się wielu ludzi. Wielu wykazuje o nią troskę. Wielu nie zadowala się jedynie narzekaniem na złą kondycję rodziny, nie zatrzymuje się na poziomie stwierdzenia, że współcześnie z rodziną źle się dzieje, nie obwieszcza jedynie jej kryzysu, tym bardziej nie wie-

\footnotetext{
31 S. Cudak, Znaczenie więzi emocjonalnych..., dz. cyt., s. 37.

32 Jan Paweł II, Dziesięcioro przykazań, dz. cyt., s. 29.
} 
ści jej upadku. Dlatego też w Rychwałdzie przy klasztorze Franciszkanów powstała fundacja o nazwie Rodzina w Służbie Człowieka.

Fundacja Rodzina w Służbie Człowieka (dalej: Fundacja RSC) jest fundacją bardzo młodą. Swoją działalność rozpoczęła w styczniu 2017 roku i pomimo tak krótkiego okresu działalności już ma w swoim dorobku sporo akcji i przedsięwzięć, a wiele różnych pomysłów czeka na realizację. Dzieło, jakim jest fundacja, nie mogłoby zaistnieć, gdyby nie prężnie działająca w Rychwałdzie wspólnota franciszkanów. Zakonnicy opiekują się sanktuarium maryjnym. Od wielu lat jest to miejsce kultu Matki Bożej Rychwałdzkiej i prężnie działający ośrodek rekolekcyjno-formacyjny. Nowa fundacja na obecnym etapie swojej działalności w dużej mierze korzysta $\mathrm{z}$ bazy i zaplecza domu rekolekcyjnego. Pewne działania i akcje są również przez nią kontynuowane.

Sam pomysł założenia fundacji zrodził się z potrzeby, z obserwacji, $\mathrm{z}$ analizy potrzeb. Jest to również konieczność prawnego umocowania różnorodnych działań. Jednak u samych jej podstaw leży głęboka troska założycieli o rodziny. Jej podstawą jest dobre małżeństwo, zdrowe i głębokie relacje między małżonkami, autentyczna więź miedzy nimi. Ojciec Bogdan Kocańda mówi, że naczelną ideą jest właśnie praca nad tymi więziami. Ale jest i cel dalekosiężny, ponieważ w działaniu fundacji chodzi nie tylko o poprawę relacji w obrębie pojedynczych rodzin, ale również o społeczeństwo, o podniesienie standardów społecznego współżycia. Jest to droga na kształt indukcji: od szczegółu do ogółu, tyle że w działaniu. Zaczynamy poprawiać pojedyncze relacje, by wpłynąć na poprawę całości. Jest w tym też ewangeliczna myśl, która wzywa do spojrzenia na własne życie, by wyrzucić z niego zło i grzech. To bardzo skuteczna droga, by przeniknąć miłością Ewangelii rzeczywistość wokół nas i jedyna, na którą mamy realny wpływ. Dopiero gdy powstanie nowy człowiek w nas, dopiero wtedy odnowi się świat wokoło $^{33}$. Im więcej ludzi, małżeństw, rodzin będzie kroczyło tą drogą, tym lepsze, bardziej solidarne będzie społeczeństwo. Idea ta przyświeca działalności fundacji.

Organem założycielskim fundacji jest klasztor św. Mikołaja Biskupa Zakonu Braci Mniejszych Konwentualnych (klasztor Franciszkanów) w Rychwałdzie. Podstawowym jej celem jest krzewienie wartości chrześcijańskich, realizacja charyzmatu franciszkańskiego oraz idei służby rodzinie

33 X. Leon-Dufour, Stownik teologii biblijnej, tłum. K. Romaniuk, Poznań 1990, s. 564. 
i dobru człowieka. Działalność fundacji jest osadzona w polskim prawie, realizuje cele społecznie użyteczne, zgodne z interesami państwa. Statut zakreśla szerokie ramy co do zasad, form i zakresu działalności. Uwzględnia działania z zakresu pomocy społecznej, w tym pomocy rodzinom i osobom w trudnej sytuacji życiowej oraz wyrównywania szans tych rodzin i osób. Chce wspierać rodziny i system pieczy zastępczej oraz udzielać nieodpłatnej pomocy prawnej, także w celu zwiększenia świadomości prawnej społeczeństwa. Pragnie prowadzić dzieła charytatywne, działać na rzecz różnych osób: kobiet i mężczyzn, niepełnosprawnych, starszych. Zamierza otoczyć troską dzieci i młodzież poprzez wspomaganie nauki, oświaty, szkolnictwa wyższego. Prowadzić działania mające na celu podtrzymywanie i upowszechnianie tradycji narodowej, pielęgnowanie polskości oraz rozwoju świadomości narodowej, obywatelskiej i kulturowej. Możliwe jest też podejmowanie zadań z zakresu ochrony i promocji zdrowia, w tym działalności leczniczej, jak również wspieranie i upowszechnianie kultury fizycznej. Troską fundacji otoczone będą również kultura i sztuka, ponieważ zamierza ona angażować się w ochronę dóbr kultury i dziedzictwa narodowego. Działalność na rzecz rodziny to również troska o rodzicielstwo, w tym szczególnie macierzyństwo, a także upowszechnianie i ochrona praw dziecka. Niezmiernie istotne jest przeciwdziałanie uzależnieniom i patologiom społecznym oraz promocja wolontariatu i jego organizacja. Człowiek żyje w określonym miejscu i konkretnym środowisku, fundacja to zauważa i w zakres swojej działalności włącza również zagadnienia z dziedziny ekologii, ochrony zwierząt i dziedzictwa przyrodniczego. Pragnie krzewić turystykę i krajoznawstwo. Fundacja otwiera się również na inne podmioty oraz organizacje pozarządowe ${ }^{34}$. Założenia statutowe Fundacji RSC są ambitne, wieloaspektowe i różnokierunkowe, ale jak przedstawię w dalszej części, nie są one ponad miarę czy określone nazbyt ambitnie.

W pierwszym roku działalności ${ }^{35}$ fundacja zainicjowała akcję Kobieta Niezawodna. W ramach tej akcji różne panie wykonały ręcznie, na drutach lub szydełku, ok. 1200 sztuk czapeczek dla niemowlaków. Zostały one przekazane do 13 domów samotnej matki na terenie Polski. Wsparcie otrzymały jednak w przypadku tej akcji nie tylko samotne matki i ich dzieci. Benefi-

34 Statut Fundacji Rodzina w Służbie Człowieka, do wglądu w siedzibie fundacji: Rychwałd, ul. Franciszkańska 1, 34-322 Gilowice.

35 Wszystkie dane zostały zaczerpnięte ze Sprawozdania z działalności fundacji za rok 2017, do wglądu w siedzibie fundacji: Rychwałd, ul. Franciszkańska 1, 34-322 Gilowice. 
cjentami tej akcji są również osoby starsze. Często siedzą one w domu z powodu chorób czy złego stanu zdrowia, to znacznie zawęża pole działania. Dzięki tej akcji również osoby w podeszłym wieku mogły pomagać na miarę swoich możliwości, znowu mogły poczuć radość, jaką daje wspólny cel i okazywanie innym dobra. To niezmiernie ważne.

Od początku działa prowadzona przez fundację Poradnia Rodzinna. Pracują w niej specjaliści, którzy oferują fachową pomoc bezpłatnie. Fundacja dopuszcza jednak - w razie konieczności, w przypadku przedłużonej terapii - organizowanie jej za pewną odpłatą. Jednak stan taki uważany jest za przejściowy i docelowo również takie działania mają się być dostępne bezpłatnie. Ideą nadrzędną jest zgromadzenie w poradni sprawnych fachowców, ale działających w duchu chrześcijańskim. Do poradni najczęściej trafiają małżonkowie z zaistniałymi już problemami. Zazwyczaj są oni kierowani przez swoich duszpasterzy. I od rozmowy z duszpasterzem, w czasie której następuje rozeznanie, zaczyna się proces terapeutyczny. Trzeba tu nadmienić, iż duszpasterz jest dyplomowanym terapeutą. W wyniku rozmowy para kierowana jest dalej. Oprócz duszpasterza działają tutaj także pedagog, 3 psycholodzy, naprotechnolog, mediator, 2 prawników. To, jaki fachowiec podejmuje się udzielania pomocy, zależy oczywiście od problemu. Podsumowując działalność poradni, możemy stwierdzić, że w roku 2017 z pomocy duszpasterzy skorzystały 72 osoby, z porad pedagoga 2 osoby. Psycholodzy pomogli 12 osobom, z naprotechnologiem spotykały się 3 pary, tyle samo par z mediatorem. Poradnia działa od poniedziałku do piątku, godziny jej otwarcia są uzależnione od potrzeb i możliwości zarówno poszukujących pomocy, jak i jej udzielających. Działalność poradni cieszy się stałym, a nawet rosnącym zainteresowaniem. Każda rozwiązana sprawa, zażegnany konflikt, rozwiązany problem czy czasami tylko próba ich załagodzenia to dla działających tam ludzi sukces. A ci, którzy doświadczyli życzliwości i pomocy, z własnego doświadczenia wiedzą, gdzie kierować tych, którzy właśnie jej potrzebują. Patrząc na te liczby, ktoś może powiedzieć, że potrzeby są znacznie większe, a skala zjawiska nazwanego kryzysem rodziny znacznie poważniejsza, ale po pierwsze, trzeba od czegoś zacząć, choćby i od jednej rodziny, a po drugie przez pryzmat każdego małżeństwa trzeba widzieć szerszą perspektywę całej rodziny wokół niego.

Fundacja organizowała rajdy turystyczne dla mężczyzn i kobiet. Rajdy są akcjami cyklicznymi i noszą odpowiednio nazwy: Jabłko w ręku Adama 
i Ewa, jaką mogę być. 55 panów było na Słowacji, na Małej Fatrze. Natomiast 102 panie wędrowały po Pieninach. Takie akcje sprzyjają odpoczynkowi, refleksji. Każdy rajd ma bowiem ściśle określony, dostosowany do konkretnych odbiorców temat. Są to wyjścia, w czasie których ciało męczy się wspinaczką, psychika odpoczywa w kontakcie z naturą i poprzez kontakt $\mathrm{z}$ innymi, a duch wzbogacany jest wspólną modlitwą, konferencją. Wspaniała forma dla lubiących wysiłek i przyrodę. Takie rajdy są dobrą okazją do przemyśleń. Są również ofertą skierowaną do określonego, ale szerszego grona odbiorców. Fundacja z dobrym słowem, przenikniętym miłością chrześcijańską wychodzi tą formą naprzeciw tym, którzy sami wędrują. Czyż nie jest to rzeczywiście Kościół „wstający z kanapy”, szukający człowieka tam, gdzie on jest?

Swoistym uzupełnieniem tych rajdów była tzw. Beskidzka Droga Wojowników. Tym razem do wspólnego wędrowania zostali zaproszeni ojcowie z nastoletnimi synami. Stawiali sobie jednak nieco większe wymagania, nadając wyprawie charakter rajdu survivalowego, czyli „im gorzej, tym lepiej". W tej formie wzięły udział 4 duety ojcowsko-synowskie. Cenną cechą różnych działań fundacji jest to, że nie rezygnuje się z organizacji imprezy $\mathrm{z}$ uwagi na niewielką liczbę uczestników, ale organizowane są takie imprezy o charakterze bardziej kameralnym.

Fundacja organizuje również formy bardziej stacjonarne. Taką formą jest Kurs matżeński, obejmujący cykl 8 spotkań. Jest to forma adresowana do małżeństw $\mathrm{z}$ różnym stażem. W kursie uczestniczą zarówno młode małżeństwa, jak i te, które razem przeżyły już wiele lat. Bogactwem kursu jest to, że odpowiada na potrzeby zarówno jednych, jak i drugich. Jest to zasługa programu i formy, która zakłada bardzo indywidualne podejście do każdego małżeństwa. Celem spotkań jest zapewnienie małżonkom czasu i przestrzeni sprzyjających umocnieniu relacji między nimi. Prowadzące spotkania pary małżeńskie najpierw w formie wykładu przekazują pewne prawdy ogólne dotyczące komunikacji, relacji, potrzeb. Po takim teoretycznym wprowadzeniu małżonkowie w miłej, randkowej atmosferze te ogólne twierdzenia odnoszą do swojego małżeństwa i rodziny poprzez wykonywanie określonych zadań przygotowanych przez prowadzących. Określone narzędzia umożliwiają, ułatwiają wzajemną komunikację i znacznie poprawiają relacje między małżonkami. Sposoby te mogą być wykorzystywane również po zakończeniu kursu. Dla wielu małżeństw takie wspólne spotka- 
nia są pierwszym po wielu latach wspólnego życia czasem, który poświęcają tylko i wyłącznie sobie i wzajemnym relacjom. Jest to wyjątkowy czas, który tworzy specyficzną kulturę spotkania, o której mówi papież Franciszek ${ }^{36}$. Niekiedy jest to spotkanie radosne, niekiedy bolesne i trudne, prowadzące do rozpoznania problemu, aż do podjęcia specjalistycznej terapii. Kurs małżeński jest inny dla każdego małżeństwa. W roku 2017 odbyły się 3 edycje, po 8 spotkań każda. Wzięło w nich udział 28 par małżeńskich. Taka forma wspiera małżeństwa, ukazuje i pomaga w kroczeniu wspólną drogą do zbawienia. Wybrana droga życiowego powołania zakłada tą wspólną drogę przeżywania swojej wiary i dążenie do zbawienia.

Wychodząc naprzeciw małżeństwom, które $\mathrm{z}$ różnych przyczyn nie mogą lub nie chcą wziąć udziału w takiej dłuższej formie, fundacja zorganizowała rekolekcyjne warsztaty weekendowe Aby byli jedno. Pierwsza edycja przebiegła pod hasłem przewodnim 1+1=11, czyli jak różnorodność staje się jednością.

Wsparciem fundacji objęci są również najmłodsi członkowie rodzin. Dla dzieci organizowane były zajęcia pod hasłem $Z$ dziada pradziada wiedza jest taka, że zdrowie i ruch to wartość jednaka. W spotkaniach wzięło udział 30 uczestników w wieku szkolnym. Projekt był realizowany we współpracy z gminą Gilowice i obejmował cykl 8 spotkań we Franciszkańskim Domu Formacyjno-Edukacyjnym w Rychwałdzie. Ich celem była promocja zdrowego, aktywnego stylu życia. W trakcie wspólnych spotkań były gry, zabawy na świeżym powietrzu oraz wspólne gotowanie - promowano kuchnię regionalną, ze szczególnym uwzględnieniem tradycji świątecznych, czyli praktyczną naukę zdrowego stylu życia i aktywności ruchowej. Dzieci mogą być ich prekursorami w swoich rodzinach. Atrakcyjną formą dla dzieci były również wyjazdy turystyczno-edukacyjne. W ich trakcie dzieci zwiedzały nieco dalsze rejony swojej małej ojczyzny, mogły poznać Wisłę i Szczyrk. Były również w Brennej, gdzie wzięły udział w regionalnych warsztatach pieczenia swojskiego chleba. Cały cykl spotkań zakończył się turniejem gier zespołowych, z hokejem na trawie oraz wspólnym ogniskiem.

Jednym $\mathrm{z}$ ostatnich działań wspomnianym w sprawozdaniu z działalności za rok 2017 był projekt skierowany do mężczyzn Mężczyzna, któremu nie wszystko jedno. Są to prelekcje otwarte. Odbyły się 3 spotkania, uczestniczyło w nich w sumie 83 panów. Prelegentami byli zaproszeni goście, m.in.:

36 D. Fares, Papież Franciszek o kulturze spotkania, Kraków 2014, s. 43. 
pisarz Robert Kościuszko, biznesmen Rafał Kimel, ekonomista Wojciech Nowicki. W swoich przemowach poruszyli odpowiednio następujące tematy: Każdy tata czyta dzieciom, Dlaczego mam stać po stronie prawdy, Kobieta i mężczyzna a Boża ekonomia. Ze względu na zainteresowanie działania te będą kontynuowane.

Nie wszystkie pomysły i inicjatywy fundacji podejmowane w omawianym roku sprawozdawczym spotkały się z zainteresowaniem. Przykładem inicjatywy, która jest zawieszona z powodu braku uczestników, była próba utworzenia grupy wsparcia Serce dla życia - dla osób po poronieniu lub okołoporodowej stracie dziecka. Fundacja zaangażowana była również w projekt Zaplecze gastronomiczne dla pielgrzymów i osób potrzebujących wsparcia.

Mówiąc o przyszłości i planach, prezes fundacji na pierwszym miejscu wskazuje wybudowanie Centrum Wsparcia Rodziny, by działalność fundacji oddzielić od działalności Domu Formacyjno-Edukacyjnego. Obecnie fundacja z konieczności korzysta z zaplecza tego domu. Pewne działania przejdą również pod patronat fundacji, np. rekolekcje uzdrowienia, warsztaty 12 kroków. Inne plany, pomysły, inicjatywy, jak mówi o. Bogdan, przynosi samo życie: rozmowy z ludźmi, którzy sami wskazują na bolączki, potrzeby współczesnego chrześcijanina. Tak jest na przykład z rekolekcjami skierowanymi do przedsiębiorców, którzy w prowadzeniu poważnych biznesów chcą kierować się zasadami chrześcijańskimi.

\section{Zamiast zakończenia}

Działalność różnych fundacji, organizacji pozarządowych jest ważnym uzupełnieniem działań instytucjonalnych. Są to działania wobec siebie komplementarne. Instytucje zazwyczaj wkraczają w życie poszczególnych rodzin, gdy zaistnieje taka bezwzględna konieczność (zgłoszenie przemocy na policję, problemy z używkami, widoczne zaniedbanie obowiązków wychowawczych, niewydolność wychowawcza itp.) Problemy się pojawiają i niekiedy przekraczają kompetencje poszczególnych członków rodziny. Niezmiernie istotne jest, by w tym momencie mogły one liczyć na fachową pomoc. By nie pozostały z nierozwiązanym problemem same, ponieważ nierozwiązany problem będzie eskalować. Jak pokazuje doświadczenie fun- 
dacji, wielu ludzi znajdujących się w jakiejś fazie kryzysu swojego małżeństwa pragnie takiej pomocy. Ważne jest, by istniały miejsca, gdzie mogą ją znaleźć. Nie bez znaczenia jest fakt darmowości takiej pomocy, przy równoczesnym wysokim jej standardzie. Pomoc nie ogranicza się do życzliwej rozmowy (chociaż i ona ma miejsce), ale jest w pełni profesjonalną diagnozą zaistniałego problemu z konkretną drogą jego rozwiązania.

Ważnym elementem działalności jest swoistego rodzaju prewencja, rozumiana jako profilaktyka problemów. Jest to cały obszar działań, które są adresowane do rodzin, a mają na celu wspólne spędzanie wolnego czasu. Jest to obecnie szczególnie ważne, by nauczyć współczesnych ojców, matki spędzania czasu ze swoimi dziećmi, by na nowo pomóc małżonkom w odkrywaniu wartości kultury spotkania i wyrwania się ze szponów idei przeciętności. Działalność fundacji skierowana jest też do ludzi młodych, by w świecie oświeceniowo-libertynistycznych poglądów wskazać niezawodną, dobrą drogę autentycznych wartości. Ponieważ tylko one mogą stanowić trwałe i mocne fundamenty małżeństwa i rodziny. Jest to również odpowiedź na trudności, które czasami występowały w rodzinnych domach młodych ludzi wstępujących w związki małżeńskie. Nie mają dobrego przykładu, dlatego potrzebują konkretnych wskazówek, jak budować swoje małżeństwo i dom.

Ważne są również wszystkie akcje, zadania - czasem cykliczne, czasem jednorazowe - nastawione na osiągnięcie jakiegoś określonego celu. Angażują one ludzi, którzy nie są na co dzień związani ze wspólnotami, nie włączają się w życie Kościoła. Jednak poprzez takie epizodyczne formy dociera do nich informacja o istnieniu takiego miejsca, takich ludzi, którzy w razie kłopotów pomogą. Otwiera to także naturalną ciekawość człowieka na nowe obszary, pokazuje nowe możliwości.

Oczywiście działalność fundacji nie jest panaceum na wszelkie bolączki. Jest tylko i aż konstruktywną odpowiedzią na zaistniałe problemy. Jest próbą zagospodarowania konkretnego obszaru działania. Bogactwem jest postawa słuchania ze strony tych, którzy tworzą fundację. Kolejne akcje, nowe pomysły są reakcją na zgłaszane problemy. Dzieła fundacji dobrze określają słowa św. Ignacego Loyoli, który zachęca, by działać tak, jakby wszystko zależało od człowieka, i ufać tak, jakby wszystko zależało od Boga. Działanie wsparte modlitwą i zaufaniem do Boga daje szansę na wiele pożytecznych inicjatyw. 


\section{Bibliografia}

Boguszewski R., Współczesne znaczenie rozumienia rodziny $w$ Polsce, „Zeszyty Naukowe KUL” 59 (2015) nr 4 (232), s. 127-148 https://www. kul.pl/files/102/articles/2015_4/zn_kul_2015_4_a_boguszewski.pdf (12.09.2018).

Borutka T., Świerczek A., Rodzina silna Bogiem. Teologiczno-duszpasterska refleksja na temat rodziny, Kraków 2013.

Cudak S., Znaczenie więzi emocjonalnych $w$ rodzinie dla prawidłowego funkcjonowania dzieci, „Pedagogika Rodziny” 2/4 (2012), s. 31-39 http:// bazhum.muzhp.pl/media//files/Pedagogika_Rodziny/Pedagogika_Rodziny-r2012-t2-n4/Pedagogika_Rodziny-r2012-t2-n4-s31-39/Pedagogika_Rodziny-r2012-t2-n4-s31-39.pdf (23.08.2018).

Fares D., Papież Franciszek o kulturze spotkania, Kraków 2014.

Jan Paweł II, Dziesięcioro przykazań, Kraków 2012.

Jan Paweł II, Rodzino, co mówisz o sobie? Dokumenty i przemówienia papieskie w Roku Rodziny, wybór tekstów i oprac. A. Świerczek, Kraków 1995.

Leon-Dufour X., Słownik teologii biblijnej, tłum. K. Romaniuk, Poznań 1990.

Lombaerts H., Osewska E., Family and Family Catechesis. A Matter of Diversification, „Acta Paedagogica Vilenensia” 20 (2008), s. 225-243.

Minorczyk A., Domagała K., Śląska rodzina pęka: Małżeństwo to przeżytek - opinie, https://dziennikzachodni.pl/slaska-rodzina-peka-malzenstwo-to-przezytek-opinie/ar/581763 (13.09.2018).

Osewska E., Jakość życia wspólnotowego rodziny jako podstawa skuteczności wychowania, „Roczniki Nauk o Rodzinie” 5 (2013), s. 5-22.

Osewska E., Wspólnota rodzinna w stużbie wychowania, „Family Forum” 4 (2014), s. 125-139.

Sprawozdanie z działalności Fundacji Rodzina w Służbie Człowieka w Rychwałdzie za rok 2017.

Stala J., Christliche Wahrheiten als Fundament einer inhaltsreichen Religionserziehung in der Familie, „The Person and the Challenges” 5 (2015) nr 2, s. $137-148$.

Stala J., Geistig behinderte Kinder religiös erziehen - Herausforderungen an Pädagogik und Katechese, „The Person and the Challenges” 4 (2014) nr 2, s. 221-234. 
Statut Fundacji Rodzina w Służbie Człowieka w Rychwałdzie.

Świerczek A., Kocik L., Wieża Babel. Obraz rodziny w ponowoczesności, Kraków 2017.

Świerczek A., Wolne związki w świetle nauczania Kościoła o małżeństwie, Kraków 2013.

Wsparcie rodziny. Założenia i praktyka w ujęciu interdyscyplinarnym, red. A. Regulska, A. Najda, Warszawa 2017.

Źródła duchowości małżeńskiej, red. K. Lubowicki, Kraków 2012. 
